Iwona SOBIERAJ

Politechnika Śląska, Gliwice

\title{
Problemy wielokulturowości na Ukrainie
}

$\mathrm{O}$ d kilkunastu lat obserwujemy proces transformacji jaki zachodzi na Ukrainie. Najbardziej zauważalne zmiany dotyczą sfery polityki i ekonomii. Na bieżąco informują o tym media. $\mathrm{O}$ wiele trudniej dostrzec zmiany struktury społecznej, językowej, narodowościowej czy zmiany postaw mieszkańców Ukrainy. To jednak właśnie od nich w znacznym stopniu zależeć będzie przebieg transformacji i kształt powstającego ładu społecznego. Społeczeństwo Ukrainy, jak wiele współczesnych społeczeństw, jest złożone $\mathrm{z}$ różnych grup narodowościowych, etnicznych i kulturowych. Jeżeli ma być społeczeństwem demokratycznym, pluralistycznym to powstający ład społeczny powinien być wypadkową dazżeń różnorodnych grup tworzących to społeczeństwo. Znaczenie i zasięg podziałów etniczno-kulturowych na Ukrainie oraz potrzeba budowania wspólnego kanonu wartości widoczne były między innymi w czasie ubiegłorocznych wyborów prezydenckich, które przerodziły się w „Pomarańczową rewolucję".

W poniższym artykule spróbuję ukazać niektóre aspekty podziałów narodowościowych, etnicznych i kulturowych na Ukrainie. Trudności jakie powstają w sytuacji negocjowania i przekształcania nowego ładu społecznego i sposoby ich przezwyciężania przedstawię na podstawie jednego z najbardziej wieloetnicznych regionów Ukrainy - Półwyspu Krymskiego.

\section{Podziały narodowościowe, etniczne i kulturowe na Ukrainie}

Zróżnicowanie narodowościowe, etniczne i kulturowe społeczeństwa Ukrainy jest faktem, natomiast wielokulturowość tego społeczeństwa należałoby analizować z uwzględnieniem wielopoziomowości tego pojęcia. $\mathrm{Na}$ występowanie trzech rodzajów zjawisk związanych z wielokulturowością wskazuje między innymi Janusz Mucha. Po pierwsze jest to poziom faktycznego zróżnicowania społeczeństwa, po drugie jest to poziom świadomości społecznej (istnienia norm społecznych aprobujących i regulujących to zróżnicowanie) i po trzecie jest to system ideologiczny 
uznający to zróżnicowanie za funkcjonalne społecznie i dążący do jego podtrzymania ${ }^{1}$.

Analiza pierwszego z wymienionych poziomów (zjawisk) wielokulturowości na Ukrainie wymaga uwzględnienia takich aspektów zróżnicowania społeczeństwa jak:

- struktura narodowościowa (w tym: mniejszości narodowe, narodowości, narody rdzenne, grupy etniczne),

- struktura językowa (problem języka ojczystego, dwujęzyczności),

- struktura wyznaniowa, oraz zmian jakie zachodzą w obrębie tych struktur.

Według spisu ludności przeprowadzonego w grudniu 2001 Ukrainę zamieszkuje ponad 130 narodowości. Największe spośród nich to Ukraińcy $(77,8 \%)$ i Rosjanie $(17,3 \%)$, następnie Białorusini (0,6\%), Mołdawianie $(0,5 \%)$, Tatarzy krymscy $(0,5 \%)$, Bułgarzy $(0,4 \%)^{2}$. Wyniki spisu - jak zauważył Piotr Andrusieczko ${ }^{3}$ - przede wszystkim wykazały zmianę dwóch tendencji, które utrzymywały się w spisach powojennych (w 1959, 1970, 1979 i 1989), mianowicie zmniejszył się o 4,8\% (w stosunku do roku 1989) odsetek ludności rosyjskiej na Ukrainie a zwiększył się o 5,1\% ludności ukraińskiej oraz zmniejszył udział języka rosyjskiego a zwiększył ukraińskiego.

Analizując regionalną strukturę narodowościową Ukrainy zauważa się przede wszystkim utrzymujący się podział na zachód - południowy wschód ze względu na proporcje Ukraińców i Rosjan w strukturze ludności. Ukraińcy stanowią największy procent ludności w obwodach: tarnopolskim $(97,8)$, iwano-frankowskim $(97,5)$, wołyńskim $(96,9)$, rowieńskim $(95,9)$, winnickim $(94,9)$, lwowskim $(94,8)$, chmielnickim $(93,9)$, czernichowskim $(93,5)$, czerkawskim $(93,1)$, kijowskim $(92,5)$, połtawskim $(91,4)$, żytomirskim $(90,3)$, kriwohradzkim $(90,1)$. Niewiele ponad połowę ludności Ukraińcy stanowią w obwodach donieckim $(56,9)$ ługańskim (58). W Autonomicznej Republice Krym są mniejszością i stanowią 24,3\%. Największy odsetek Rosjan zamieszkuje w Autonomicznej Repu-

1 J. Mucha, Oblicza etniczności. Studia teoretyczne i empiryczne, Kraków 2005, s. $51-52$.

2 F. Zastawnyj, Wsieukrainskyj perepys naselennia 2002, Narodoznawczi Studii, Lwowski Uniwersytet im. I. Franka, Lwiw 2003.

${ }^{3}$ P. Andrusieczko, Zmiany struktury narodowościowej i językowej na Ukrainie w kontekście wyników spisu z 2001 roku, „Sprawy Narodowościowe. Seria Nowa”, R. 2004, z. 24-25, Poznań-Warszawa 2004, s. 105-115. 
blice Krym: 58,3, w obwodach ługańskim (39), donieckim $(38,2)$, charkowskim $(25,6)$, zaporoskim 24,7$)^{4}$. Porównując regionalną strukturę narodowościową z roku 1989 do roku 2001 największe zmiany proporcji narodowościowych wystąiły między innymi w Autonomicznej Republice Krym, gdzie udział procentowy Rosjan zmniejszył się o 7,3, udział Ukraińców wzrósł o 2,4, natomiast liczba Tatarów krymskich wzrosła 6,3 razy. W obwodzie iwanofrankowskim i lwowskim udział procentowy Rosjan zmniejszył się o ponad połowę. Ukraińców przybyło najwięcej w Kijowie (107\% w stosunku do roku 1989). Poza Autonomiczną Republiką Krym na Ukrainie duże skupiska mniejszości narodowych i etnicznych znajdują się w obwodach: odeskim (m.in.: Bułgarzy, Mołdawianie, Gagauzi), zakarpackim (Węgrzy, Rumuni, Cyganie), czerniowieckim (Rumuni, Mołdawianie) $)^{5}$.

Wśród innych narodowości, które wykazał spis, zmiany (w stosunku do spisu z 1989) w największym stopniu dotyczyły takich grup jak: Tatarzy krymscy, Żydzi, Ormianie, Gruzini, Białorusini, Polacy, Azerowie i Rumuni. Spadek liczebności dotyczył przede wszystkim Żydów, Białorusinów, Polaków i Mołdawian. Największy wzrost dotyczył Tatarów krymskich, Ormian, Gruzinów, Azerów i Rumunów. Do spadku liczebności wielu grup przyczyniła się między innymi migracja, szczególnie emigracja Żydów do Izraela i Rosjan do WNP (później Federacji Rosyjskiej) między innymi z obwodów dniepropietrowskiego, donieckiego, zaporowskiego, łuchańskiego, charkowskiego, w których w roku 1994 odnotowano ujemne saldo migracyjne. Główne państwa, do których kierowali się emigranci to WNP, Izrael, Stany Zjednoczone i Niemcy ${ }^{6}$. Przyczyną zwiększenia się liczebności Tatarów krymskich i Ormian była repatriacja. Deportowane w latach 1944-1946 narody (Tatarzy krymscy, Niemcy, Grecy, Bułgarzy, Ormianie i inne) już w latach 80 . rozpoczęły powroty z miejsc deportacji. Na masową skalę powroty te rozpoczęły się w latach 90 . i dotyczyły przede wszystkim Tatarów krymskich. W okresie ponad 13 lat na Ukrainę (przede wszystkim na Krym) przybyło ponad 250 tys. Tatarów krymskich i około 12 tysięcy Niemców, Greków, Bułgarów, Orimian

4 www.ukrstat.gov.ua.

5 www.ukrstat.gov.ua.

${ }^{6}$ P. Andrusieczko, Zmiany struktury narodowościowej i językowej na Ukrainie w kontekście wyników spisu z 2001 roku, „Sprawy Narodowościowe. Seria Nowa”, R. 2004, z. 24-25, Poznań-Warszawa 2004, s. 106-110.

7 F. Zastawnyj, W. Kusiński, Ukraina. Przyroda-Ludność-Gospodarka, Warszawa 2003, s. 149. 
W analizie przemian społecznych na Ukrainie ważną rolę odgrywa struktura językowa społeczeństwa. Język bowiem pełni nie tylko funkcje komunikacyjne, ale jest ważnym czynnikiem kształtowania się tożsamości jednostki. Do spadku liczebności takich grup jak Żydzi, Białorusini, Polacy, Rosjanie przyczyniła się w znacznym stopniu również polityka asymilacyjna, w tym językowa. Analizując strukturę językową i rozmieszczenie geograficzne tych grup w przypadku Żydów i Białorusinów była to rusyfikacja. W przypadku Polaków - ukrainizacja. Spadek liczebności tych grup można by częściowo tłumaczyć zmianą deklaracji co do przynależności narodowej.

Na Ukrainie językiem państwowym jest ukraiński, natomiast specjalny status języka rosyjskiego został potwierdzony zapisem w konstytucji Ukrainy. Podobnie jak w przypadku struktury narodowościowej w spisie z 2001 roku zmienił się trend z poprzednich spisów powojennych. W stosunku do roku 1989 zwiększył się udział języka ukraińskiego wśród mieszkańców Ukrainy (o 2,8\%), natomiast zmniejszył się udział języka rosyjskiego o 3,2\%. Obecnie 67,5\% mieszkańców Ukrainy język ukraiński określiło jako swój język ojczysty, a 29,6\% uznało za ojczysty język rosyjski ${ }^{8}$.

Przedstawiona struktura językowa konstytuuje trzy największe grupy językowe na Ukrainie: Ukraińców ukraińskojęzycznych, Ukraińców rosyjskojęzycznych i Rosjan rosyjskojęzycznych. W rzeczywistości jednak, jak wykazują badania socjologiczne, znaczna część Ukraińców posługuje się na co dzień językiem rosyjskim, a deklarowaną w spisie mowę ojczystą można traktować bardziej jako manifestację narodowościową. Duży jest również zakres dwujęzyczności (szczególnie w dużych miastach) zarówno wśród Ukraińców jak i coraz większy wśród Rosjan. Jeżeli chodzi o ogólne tendencje można przypuszczać, że znaczenie języka ukraińskiego będzie wzrastało na Ukrainie. Jak wykazują badania socjologiczne przeprowadzone w 2000 roku 94,7\% Ukraińców i 83,4\% Rosjan uważa, że ich dzieci powinny uczyć się języka Ukraińskiego ${ }^{9}$. Nie wykluczone też, że Ukraina zostanie jeszcze na długo krajem dwujęzycznym. Poza Rosjanami, którzy język rosyjski jako ojczysty deklarowali w 95,9\% wśród innych grup mniejszościowych, język własnej narodowości dominuje u Węgrów (95,4\%), Tatarów krymskich (92\%), Rumunów (91,7\%).

8 www.ukrstat.gov.ua.

9 P. Andrusieczko, Zmiany struktury narodowościowej i językowej na Ukrainie w kontekście wyników spisu z 2001 roku, „Sprawy Narodowościowe. Seria Nowa”, R. 2004, z. 24-25, Poznań-Warszawa 2004, s. 105-115. 
Najbardziej zukrainizowaną grupą są Polacy - w 71\% deklarowali język ukraiński jako ojczysty, w 15,6\% język rosyjski i tylko w 12,9\% język polski. Najbardziej zrusyfikowaną grupą okazali się Żydzi w 83\% deklarowali język rosyjski (w 3,1\% ojczysty) i Grecy 88,5\% - deklarowało język rosyjski (6,4\% grecki). Stan ten związany jest z postępem procesów asymilacyjnych wśród tych grup, które przyjmująjęzyk dominujący w regionie, w którym mieszkają ${ }^{10}$.

Analiza struktury narodowościowej, a także językowej w oparciu o dane spisowe pozwala odpowiedzieć na niektóre pytania o zróżnicowanie społeczeństwa Ukrainy. Ukazuje jednak obraz uproszczony nie oddając szeregu ważnych dla poznania problemu wielokulturowości zjawisk, zachodzących w obrębie trzech wyróżnionych na początku poziomów. Są to przede wszystkim kwestie zróżnicowanych identyfikacji etnicznych i narodowych (np. podwójnych, złożonych), problem małżeństw mieszanych, istnienia dystansu społecznego, funkcjonowania wspólnego kanonu wartości centralnych, ideologie dotyczące polityki narodowościowej propagowane władze (np. wielokulturowości, tygla czy asymilacji). Zagadnienia te wymagają intensywnych badań empirycznych zarówno w skali całego społeczeństwa jak też w poszczególnych regionach Ukrainy.

\section{Trudności negocjowania wielokulturowego ładu na Krymie}

Obecnie sytuację etniczną na Krymie, który stanowi Autonomiczną Republikę Ukrainy, determinują relacje pomiędzy trzema największymi i najbardziej aktywnymi grupami: Rosjanami, Tatarami krymskimi i Ukraińcami. Według spisu ludności z 2001 roku Rosjanie stanowią 58\% ludności Krymu, Ukraińcy - 24\%, a Tatarzy krymscy $12 \%{ }^{11}$, natomiast dane te wg spisu z 1989 roku stanowiły odpowiednio: 65\%, 26\% i 1,9\%. Biorąc pod uwagę dynamikę etniczną na Półwyspie, można się spodziewać, że w przyszłości największy wpływ na sytuację społeczną i polityczną na Krymie będzie wywierała grupa Tatarów krymskich, rola społeczności ukraińskiej będzie rosła, podczas gdy rola Rosjan będzie zmniejszała się ${ }^{12}$. Na kształt

10 www.ukrstat.gov.ua.

11 F. Zastawnyj, Wsieukrainskyj perepys naselennia 2002, Narodoznawczi Studii, Lwowski Uniwersytet im. I. Franka, Lwiw 2003.

12 Porównaj: W. Jewtuch, Ethnic Dynamics of Crimea, w: Materials of International Conference Developments in Crimea: Challenges for Ukraine and Implications for Regional Security, October 23-25, Kyiv, Ukraine 1994. 
tych relacji składa się jeszcze wiele innych czynników społeczno-politycznych i ekonomicznych, najważniejsze $\mathrm{z}$ nich to:

1) stosunki ukraińsko-rosyjskie na linii Kijów-Moskwa,

2) stosunki ukraińsko-rosyjskie na Półwyspie,

3) stosunki pomiędzy władzami Autonomii a Kijowem,

4) stosunki pomiędzy władzami Ukrainy a Tatarami krymskimi,

5) stosunki pomiędzy władzami Autonomii a Tatarami krymskimi,

6) masowy napływ Tatarów krymskich na Półwysep i relacje pomiędzy Tatarami a innymi grupami etnicznymi,

7) wpływ Turcji (szczególnie w zakresie wspomagania odrodzenia islamu wśród Tatarów na Półwyspie),

8) wpływ Rosji - na polityczną działalność większości rosyjskiej na Półwyspie.

W przeszłości przeważającym modelem integracji społeczeństw wieloetnicznych był model kulturowej jednolitości państwa, który opierał się na założeniu tożsamości narodu i państwa. Ten model jest dzisiaj w głębokim kryzysie, po tym jak w pierwszej połowie naszego wieku w wielu krajach realizowany był z tragicznymi skutkami - przy użyciu siły. Okrucieństwo i przemoc były konsekwencją przymusowej asymilacji, która miała wyeliminować istniejące jeszcze różnice, uznane za szkodliwe dla życia zbiorowego ${ }^{13}$. Problem ten w odniesieniu do narodów byłego Związku Radzieckiego podejmuje Swietłana Czerwonnaja. Wśród tych narodów główną tożsamością stała się tożsamość obywatela ZSRR, a nie przynależność do grupy narodowej czy etnicznej. Integracja sprowadzała się w zasadzie do dominacji kultury rosyjskiej ${ }^{14}$.

Obecnie na Krymie jesteśmy świadkami odwrotnego procesu historycznego - odmowy asymilacji kulturowej i obrony wielości kultur i różnorodności grup etnicznych. Na Ukrainie zaczyna się mówić o „polityce różnic", a w tym nowym klimacie kulturowym budzą się na nowo dawno stłumione tożsamości etniczne, jako wyraz fundamentalnego prawa różnych grup ludzkich. W Konstytucji Autonomicznej Republiki Krym przyjętej przez Najwyższą Radę Ukrainy w 1998 r. - społeczeństwu zagwarantowano prawa pozwalające na swobodną inicjatywę w tworzeniu

13 G. Dal Ferro, Europa: od wielokulturowości do interkultury, „Wielokulturowość" 1999, nr 1.

14 S. Czernonnaja, Wieloetniczny kompleks współczesnej kultury rosyjskiej: dialog czy konfrontacja religii, narodów, państw, w: Dylematy tożsamości europejskich pod koniec drugiego tysiaclecia, red. J. Mucha, W. Olszewski, Toruń 1997, s. 119-195. 
organizacji i wspólnot, gwarantującą możliwość zalegalizowania działalności kulturowej, religijnej i innej, różnych grup etnicznych. Szeroki zakres praw (jak wprowadzenie trzech języków urzędowych: ukraińskiego, rosyjskiego i krymsko-tatarskiego, szkół z językiem narodowym jako wykładowym) zmierzających do ochrony tożsamości etnicznych grup zamieszkujących Półwysep, nie idzie jednak w parze z niezbędnymi do jego wprowadzenia środkami materialnymi. O dyskryminacji Ukraińców na Krymie może świadczyć polityka oświatowa władz krymskich, które blokują wszelkie inicjatywy powstania szkół czy klas z językiem ukraińskim. W 1993 roku 96\% szkół na Krymie były to szkoły rosyjskojęzyczne, a do 1996 roku nie było na Półwyspie ani jednej szkoły z językiem ukraińskim $^{15}$. Jest to więc postulowane dążenie do utrwalania odrębności kulturowo-etnicznych grup Krymu, które w rzeczywistości pozostaje uzależnione od inicjatywy i operatywności przedstawicieli tych grup w zdobywaniu niezbędnych środków oraz od pomocy z zewnątrz (jak np. pomoc Tatarom krymskim ze strony Turcji).

Władze Krymu, podobnie jak władze Ukrainy, oficjalnie propagują ideę integracji repatriantów w wieloetniczne społeczeństwo Krymu. Przyjęte zostały między innymi „Państwowy program adaptacji i integracji w ukraińskie społeczeństwo deportowanych Tatarów i obywateli innych grup etnicznych"16. Powstaje jednak pytanie, na ile koncepcje tych dwóch stron są ze sobą zbieżne, zarówno w kwestii rozumienia pojęcia integracji, sposobu doprowadzenia do niej, jak i przede wszystkim w kwestii przyszłego efektu, jaki chciałyby osiaggnąć? Koncepcja integracji zakłada zazwyczaj „proces wzajemnego przenikania się i łączenia w jedną złożoną, ale mniej lub bardziej zharmonizowaną całość, kultury mniejszościowych grup etnicznych (lub jej elementów) z kulturą grupy większościowej. Jej podstawą jest dwustronność procesów oddziaływania między grupą mniejszościową i większościową, przy czym integrującą jest kultura grupy większościowej, a integrowaną kultura grupy mniejszościowej”"17. Dla mniejszości ważne są przede wszystkim społeczne konsekwencje, jakie wynikać mogą z przyjęcia określonej polityki integracyjnej. Proces integracji zakłada

15 W. Baluk, Koncepcje polityki narodowościowej Ukrainy. Tradycje i współczesność, Wrocław 2002, s. 249.

16 I. M. Pribytkowa, Sowriemiennyje migracjonnyje procesy: obustrojstwo i adaptacja rannie deportowanych krymskich tatar w Krymu, „Socjologia: teoria, metody, marketing" 2000, nr 1, s. 152-162.

17 G. Janusz, P. Bajda, Prawa mniejszości narodowych. Standardy europejskie, Warszawa 2000, s. 19-20. 
przełamywanie barier utrudniających bądź uniemożliwiających komunikację oraz akceptację wspólnych systemów norm i wartości.

Działania instytucjonalne zmierzające do wsparcia procesu integracji Tatarów krymskich ze społeczeństwem Półwyspu, są stopniowo przeprowadzane i rozszerzane dzięki współpracy organizacji międzynarodowych ${ }^{18}$. Jednak nie zostaną one uwieńczone sukcesem, jeżeli proces integracji nie będzie akceptowany przez większość społeczeństwa Krymu. Czynnikiem, który najbardziej integruje grupy etniczne Krymu jest język rosyjski $^{19}$. Znajomość i używanie tego samego języka nie jest jednak wystarczającym warunkiem do zapobiegania poważnym, międzyetnicznym konfliktom na Krymie. Konieczne jest dokonanie i utwierdzenie pozytywnych zmian w świadomości mieszkańców Krymu, poszerzenie międzyetnicznego kanonu wartości centralnych o takie wartości jak równouprawnienie i tolerancję wobec wszystkich grup etnicznych zamieszkujących na Krymie.

Pomimo istnienia szeregu barier w komunikacji międzyetnicznej na Krymie oraz nakładania się różnych konfliktów, wzmagającego tendencje dezintegracyjne, zauważyć należy, że władzom Ukrainy oraz Autonomicznej Republiki Krym udaje się dotychczas łagodzić poważne antagonizmy i rozwiązywać zaistniałe sytuacje konfliktowe w drodze negocjacji i porozumienia stron. Stanowi to niewątpliwy sukces społeczeństwa Krymu i Ukrainy, szczególnie biorąc pod uwagę głębokie zmiany demograficzne, ekonomiczne i społeczne, jakie zaszły na Półwyspie w ostatnim okresie oraz problemy ekonomiczne. Pojawienie się na scenie politycznej i społecznej Tatarów krymskich spowodowało nie tylko zmianę struktury społecznej na Krymie, ale wywarło również wpływ na politykę etniczną, kulturową i gospodarczą Krymu i Ukrainy.

\section{Instytucjonalne formy współdziałania etnicznego na Krymie}

Aktywność odradzających się na Krymie grup etnicznych wyraża się między innymi poprzez tworzenie związków mniejszościowych, stowa-

18 O. Sokołowa, Pidnisienia suspilnoj aktywnosti w Krymu, „Widrodżienia” 1996, nr 2 (10), s. 42.

19 Badania własne na Krymie przeprowadzone w latach 1996-2000. W czasie trzykrotnego pobytu na Półwyspie (w sumie około 11 tygodni) uzyskałam 36 wywiadów i 117 ankiet oraz liczne materiały źródłowe i dane statystyczne z organizacji i stowarzyszeń grup mniejszościowych Krymu. 
rzyszeń, wspólnot. Do 2000 roku zarejestrowano na Krymie 23 takie organizacje $^{20}$ :

Ta forma inicjatywy obywatelskiej wzbudzała aprobatę przedstawicieli większości grup etnicznych. Wielokulturowość Półwyspu postrzegana była jako jego atut, który wzbogaca tradycję i kulturę, ale również przyciagga środki międzynarodowych organizacji. Bogactwo kultur stanowi również niewątpliwą atrakcję turystyczną Krymu. Rozumiejąc tą zależność, przedstawiciele niemal wszystkich grup etnicznych porozumieli się tworząc organizację koordynującą ich działalność oraz będącą płaszczyzną współpracy międzyetnicznej ${ }^{21}$.

Zrzeszenie Wspólnot i Towarzystw Narodowych Krymu - zarejestrowane zostało 31 sierpnia 1995 roku. W 2000 roku skupiało 23 wspólnoty z 300 oddziałami na terenie Krymu. Jako główne cele zrzeszenie postawiło sobie:

1) rozwijanie porozumienia i współpracy pomiędzy grupami etnicznymi na Krymie,

2) koordynowanie ich działań,

3) wspieranie rozwoju kultur narodowych.

Zrzeszenie w ramach swojej działalności współpracuje z Ministerstwem Kultury Ukrainy w organizacji między innymi: corocznych festiwali kultur grup narodowych i etnicznych na Krymie oraz cyklu konferencji naukowych poświęconych problematyce wieloetniczności Krymu „Dialog kultur - etniczne realia i przyszłość Krymu”. Poza tym Zrzeszenie utrzymuje stałą łączność i współpracę z organizacjami ukraińskimi i zagranicznymi w celu pozyskiwania środków finansowych oraz pomocy specjalistów. Zrzeszenie wydaje wspólną gazetę narodów Krymu „Wspólny Dom”.

Poza zrzeszeniem, przy Parlamencie i Radzie Ministrów ARK działają jeszcze organy pomocnicze i doradcze zajmujące się problemami związanymi z wieloetnicznością Krymu i repatriacją deportowanych grup etnicznych. Sa to:

1. Międzynarodowa Rada przy Radzie Ministrów ARK - powołana 25 kwietnia 1998 roku przez Radę Ministrów. Stanowi konstytucyjny organ powołany w celu ochrony praw i interesów grup etnicznych Krymu. Do głównych zadań Rady należy: udział w przygotowaniu ustaw oraz programów zmierzających do rozwoju narodowych kultur

20 Badania własne: dane uzyskane z biura Zrzeszenia Wspólnot i Towarzystw Narodowych Krymu w Symferopolu w 2000 r.

21 Badania własne na Krymie w latach 1996-2000. 
Krymu, ochrony praw przedstawicieli wszystkich narodowości będących obywatelami ARK, konsultacja problemów etnicznych Krymu $\mathrm{z}$ innymi konstytucyjnymi organami, przygotowywanie konferencji dotyczących problemów etnokulturowych Krymu.

2. Republikański Komitet do spraw narodowości i deportowanych obywateli - powołany w 17 listopada 1993 roku przez Radę Ministrów ARK. Do jego zadań należy między innymi: informowanie Rady Ministrów o sytuacji etnicznej na Półwyspie, badanie problemów związanych z socjalno-kulturową adaptacją repatriantów, kontrola efektywnego wykorzystania środków budżetowych (z budżetu Ukrainy) przeznaczonych na pomoc repatriantom, ochrona praw repatriantów w oparciu o konwencje międzynarodowe oraz prawo ukraińskie.

3. Stała Komisja Najwyższej Rady Autonomicznej Republiki Krym do spraw kultury, relacji międzyetnicznych i problemów deportowanych obywateli - stanowi od 1998 roku organ pomocniczy Najwyższej Rady ARK. Głównymi zadaniami Komisji jest doradztwo oraz pomoc w przygotowywaniu postanowień i aktów prawnych dotyczących polityki etnicznej i kulturalnej ARK. Zajmuje się między innymi problemami związanymi z reintegracją repatriantów w społeczeństwo Krymu, ochroną zabytków i pamiątek kultury grup etnicznych na Krymie.

Problematyka stosunków etnicznych na Krymie stanowi również przedmiot zainteresowań Centrum Badań Etnicznych przy Katedrze Politologii i Socjologii Uniwersytetu Taurudzkiego w Symferopolu, które współorganizuje między innymi cykliczne spotkania pod nazwą, „Okrąły stół” zainicjowane w 1994 roku przez OBWE i wspierane przez program pomocy Organizacji Narodów Zjednoczonych. Celem tych spotkań jest znajdowanie odpowiednich rozwiązań bieżących problemów migracyjnych i integracyjnych Krymu. W spotkaniach tych biorą udział przedstawiciele nauki, władz Krymu i Ukrainy, organizacji pozarządowych ${ }^{22}$.

Działania na rzecz integracji społeczeństwa Krymu oraz odrodzenia się kultur etnicznych prowadzi szereg organizacji międzynarodowych i fundacji. Między innymi Rada Europy, Organizacja Bezpieczeństwa i Współpracy w Europie, Organizacja Narodów Zjednoczonych. Aktywne działania prowadzi również Międzynarodowa Fundacja „Odrodzenie”, która między innymi finansuje tworzenie nowych organizacji pozarządo-

22 A. Maszczenko, Uczienyje TNU nadiejutsa w Krymu mieżetniczeskogo sogłasia, „Tawriczeskij Uniwersytet” 2000, nr 6 (891). 
wych na Krymie, popiera rozwój inicjatyw lokalnych oraz zmierza do koordynacji instytucji rządowych (przede wszystkim ukraińskich) oraz pozarządowych działających na rzecz integracji na Krymie. Zasadniczym dążeniem Fundacji jest zaktywizowanie obywateli Krymu do udziału w programach integracji. W ramach programu „Integracja w ukraińskie społeczeństwo narodów krymsko-tatarskiego, Bułgarów, Ormian, Greków i Niemców, którzy zaznali deportacji” realizowane były następujące postulaty:

1) rozwój szkół narodowych,

2) organizacja i wsparcie prasy różnych grup etnicznych w językach narodowych,

3) rozwój organizacji pozarządowych,

4) rozwój kultur narodowych Krymu,

5) wsparcie inicjatyw lokalnych ${ }^{23}$.

Efekty działania tych organizacji widoczne są w życiu społecznym Krymu. Na Półwyspie ukazuje się stale od 1995 roku ponad 10 gazet różnych grup etnicznych. Pierwsza niezależna gazeta krymsko-tatarska „Kirim” (od czasu rozpoczęcia powrotów z deportacji) ukazała się w 1990 roku początkowo jako dodatek do gazety „Krymska Prawda”, ale po kilku miesiącach jako odrębna gazeta w języku krymsko-tatarskim. W lipcu $1990 \mathrm{r}$. powstała również nieoficjalna gazeta Tatarów krymskich „Advet” (powrót $)^{24}$. Z czasem gazet tych zaczęło przybywać. Prasa narodowa pełni ważną rolę w procesie integracji na poziomie regionalnym. Do poprawy komunikacji międzyetnicznej przyczyniają się również coraz powszechniejsze na Krymie gazety dwujęzyczne.

Zainteresowanie problemem integracji uwidacznia się również w działaniach parlamentu Ukrainy i ARK. W okresie ostatnich 10 lat uchwalone zostało kilkanaście aktów prawnych odnoszących się bezpośrednio do problemu integracji społeczeństwa Krymu oraz repatriacji. Między innymi „Państwowy program adaptacji i integracji w ukraińskie społeczeństwo deportowanych Tatarów krymskich i obywateli innych grup etnicznych”, „Priorytetowe środki na osadnictwo i adaptację Tatarów krymskich i innych grup etnicznych, które powróciły i mieszkają w Autonomicznej Republice Krym”, „O sposobach rozwiązywania politycznych, prawnych, socjalno-ekonomicznych i etnicznych problemów w ARK”. Rząd corocz-

23 L. Brudko, Cultural integration of Crimean Tatars, dostępny w Internecie: http://www.aspecst.crimeastar.net.

24 Ibidem. 
nie przeznacza środki z budżetu Ukrainy na cele związane z repatriacją $\mathrm{i}$ integracją na Krymie. Działania instytucjonalne zmierzające do wspierania procesu integracji na Krymie, aby stały się efektywne wymagają zaangażowania się wszystkich warstw społecznych. Bez oddolnej inicjatywy oraz chęci przeprowadzenie tak głębokich zamian społecznych może okazać się niezwykle trudne. Konieczne jest zatem przełamanie nawyków bierności, braku zaufania do władz, nietolerancji i uprzedzeń na rzecz formowania się społeczeństwa obywatelskiego. Idea ta jest być może jeszcze odległa, jednak powinna wyznaczać kierunek przyszłych zmian.

W wyniku częstego i intensywnego kontaktu z obcymi, do jakiego dochodzi w sytuacji pogranicza, w świadomości jednostek z różnych grup etnicznych dokonywać się mogą głębokie przemiany. Mogą one doprowadzić do zamknięcia się, chroniącego własną zagrożoną tożsamość, izolacji bądź podziału własnych zachowań na te, które odnoszą się do kontaktu z obcymi i te, które dotyczą własnej grupy. W sytuacji kontaktu kulturowego możliwa i bardziej pożądana jest przemiana świadomości w kierunku przyjmowania postaw otwartości i poszerzenia kręgu swojskości o spotkane grupy i ich kultury. Postawa otwartości i akceptacji dla „obcych", uznania ich za równych sobie i zdolnych do partnerstwa oraz zachowania odrębnej tożsamości kulturowej - jest wymaganiem bardzo trudnym, nie tylko dla mniejszości, ale i dla większości.

Działania, jakie powinny zostać podjęte przez lokalne władze na Krymie oraz rząd ukraiński, w celu zwiększenia integracji społecznej oraz zapewnienia rozwoju relacji etnicznych na Półwyspie, określane były w programach i raportach wielu organizacji. Generalnie sprowadzają się one do kilku głównych postulatów:

1. Zagwarantowanie wszystkim mniejszościom, w szczególności grupom repatriantów równych praw obywatelskich oraz szans ich reprezentacji w parlamencie.

2. Wspieranie rozwoju grup etnicznych Krymu, ich kultur, tradycji, języków i religii.

3. Powstanie edukacji wieloetnicznej promującej tolerancję, współpracę oraz komunikację międzyetniczną opartą na wspólnym dla wszystkich grup etnicznych kanonie wartości podstawowych.

4. Rozwój idei społeczeństwa obywatelskiego i wsparcie rozwoju „trzeciego sektora".

5. Konsolidacja i koordynacja wszystkich programów organizacji rządowych, pozarządowych i międzynarodowych tak, aby przeznaczone na nie fundusze skierowane były na właściwe i najpilniejsze cele. 
Poza określonym kierunkiem przemian konieczne jest również opracowanie sposobów wczesnego wykrywania nieuchronnych w zróżnicowanym etnicznie społeczeństwie konfliktów, ich diagnozowania oraz wypracowanie metod ich rozwiązywania bądź regulacji.

\section{Summary}

Since the proclamation of its independence Ukraine has been struggling with numerous serious social problems. They are partly inherited after the Soviet Union, but partly they reflect the processes emerging under the new social and political circumstances. The latter involve the growing social migration and particularly the migration of Crimean Tartars to the Crimea and the issues of appropriate ethnic relations between various ethnic groups in Ukraine. Both issues mainly concern the southern frontier of Ukraine and they are particularly intensive in the Crimea, which constitutes an Autonomous Republic of Ukraine. These processes create a highly complex national situation in the Crimea, which is outlined in the paper. 